The plan here proposed is not complicated ; it depends for its successful working on heat, which every habitation requires every day; it involves no other demands than bringing into practical use the heated surroundings of every kitchen fireplace. In the case of private houses and localities where the first-named facilities for the wholesale purification of the sewers does not exist, its adoption will prove an incalculable blessing, for it will externinate an enemy which has contimually conspired to undermine and destroy one of his most valuable possessions, health.

Richand Lee, Junr.

\title{
Forty Cases of Illness following Sanitary Neglect.
}

THAT the neglect of decent arrangements about human dwellings can possibly cause disease, is, strange to say, a truth still unadmitted by many of the commumity. With some this is due to ignorance or indifference; with others to self-interest, because it would cost them money or trouble to put things straight. Some people stand up for individual or corporate rights. Liberty of the subject is made to confer the privilege of cherishing small-pox in one's house, or any accumulation of filth, or other insanitary arrangements, on one's own ground. One man claims a prescriptive right of drainage into the next open ditch; another thinks it very proper to pile up stablemanure under his neighbour's windows; another has a vested interest in bone-crushing, rag-sorting, soap-boiling, candle-maling, or some other process that poisons the air. Such a man feels bound to maintain in its existing condition some low and miserable but lucrative house-property ; and such another man has on that spot an established right of horse-pond, which none may touch. With these persons you cannot argue; the law may now and then do so with effect, but not always; and there are many sanitary duties which are private and personal, with which it is not the province of the law to interfere. But it is possible by perseverance to convince the ignorant, and to build up and maintain a certain public opinion on the subject, by accumulating and setting forth instance upon instance of the production of disense by the neglect of sanitary measures. It is to contribute towards this that I submit the following cases from my own personal experience.

1. Several boys in a school of a superior class were attacked with fever. There were three or four severe cases, and one death. Large cesspools existed close about the foundations of the house, and bad smells were at times perceived.

2. Two cases of fever were received into a hospital. Similar cases had often been admitted, without any bad effects. But on this occasion the fever spread. Four persons, if not six, died, and about four more were dangerously ill. Bad smells had been noticed about the house; and shortly after the fever, it was discovered that several enormous cesspools, full of fotid matter, were under the foundations 
of the house, and that one of them in particular sent its vapours through numerous openings into one of the rooms.

3. A bad case of phlegmonous erysipelas was admitted into a London hospital. The patient stated that nine days before, a large sewer, passing under her house, was opened; and in the afternoon of the same day, she was attacked with shivering, which recurred for two or three days, when phlegmonous erysipelas came on. This patient died.

4. A lady died of fever in a house the drainage of which was supposed to be perfect. I examined the premises. On entering the back-yard, I was instantly sensible of a strong offensive smell, and on looking lound for its cause, discovered a large open grating, communicating directly with one of the town sewers. This grating had never been noticed, and no doubt had emitted the poisonous miassna, which must constantly have entered all the back windows and doors of the house. Further search disclosed a long rat-hole opening beneath the dining-room floor and passing directly into the same sewer. These and other matters were immediately put to rights, and no further illness arose.

5. A lady in London had low fever, which ran a very lingering course, ending in recovery. She had often been annoyed with offensive smells coming from the back of the house, believed to arise from a cow-yard.

6. A case of low fever occurred in a sea-port town in a house near the quay. The town was drained into the harbour, and the mud at low water all along the quay sent up a considerable stench. The streets and alleys of this town abounded in cesspools and accumulations of filth; and fever was vely common.

7. A case of febricula also occurred there in a young man engnged in breaking up a dirty old ship.

8. An infant was attacked with capillary bronchitis. He lived in one of a nest of cottages belonging to an owner too poor to keep them in order, and there were abominable collections of filth. The disease became asthenic, and the child died.

9. A father, mother, and several children, were all successively ill with inflammation of the mouth. Their cottage was absolutely without either ventilation or outlet both at the sides and back.

10. A woman with phlegmonous erysipelas, caused by smells from a cesspool.

11. A cbild with low bronchitis and canker of the mouth, died. The residence was over a stable, and the smell of stable manure was constantly present in the roons.

12 to 30 . Bronchitis, fever, \&c., connected with foul air.

The cases from No. 7 to No. 30 were dispensary out-patients visited at their own homes. In each there was distinct exposure to sewer gas, emanations from cesspools, or the smell of stable-manure -which last I have always noticed to be highly deleterious.

31. Child with diphtheria. On entering the house, the smell of sewer-gas was instantly perceived ; and on inquiry, it was found that the bell-traps had been removed from two sinks, and had so remained for some days. 
32. An artisan came to me with sore throat. After inspection, I told him it was caused by sewer-gas. He assured me the drains, dc., were in perfect order in his house, and that he was excessively particular about such matters. After a few minutes, he suddenly recollected, that several days previously he had been employed for some time in putting a lock to a door, where there was an offensive smell as from sewers, which annoved him and seemed to get into his throat.

33. A young lady was ill for some dnys with asthenic bronchitis, after being exposed to emanations coming in at a window from a clusthole which the dustmen had neglected to clear out.

34. A tradesman's wife was several times ill with asthenic bronchitis, from breathing exhalations from a refuse-heap.

35. A gentleman was attacked with trachenl catarrh, partly from getting wet, partly from breathing foul air arising from the mud of a tidal estuary and offensive emanations from a brook into which housedrainage fell. A lady was severely ill with influenza, brought on by the smell of the mud of a harbour at low water, to which smell she was once exposed for a few hours.

36. For some years the young children of a small tradesman were attacked once or twice a year with erysipelas of the head or face, sometimes one child, sometimes another. The closet, as usual, adjoined the house at the back, amd $I$ have no doubt that emanations from it got into the house.

37. During many years the children of a wealthy farmer were frequently ailing, though without any distinctly zymotic illness. Large farmyards were close to the house, around which the smeil. from manure, \&ce., was usually perceptible. I do not doubt that in this case, some of the illnesses were caused by these emanations, though this could never be ascertinined with certainty. I was of a similar opinion respecting several other families, but could not trace anything out to act upon.

38. An infint, frequently ill with one ailment or other, lived in a house at the foot of a hill. The drainage was suspected, but not known, to be wrong. The child was moved to another house a little way up the hill, and from that time was always well and hearty.

39. An infint was ill with canker of the mouth, brought on by foul air and bad food.

40. A gentleman requested me to see his coachman, who was ill with fever. He was living in well-appointed rooms over the stable, which was carefully ceiled; yet the smell of stalble-manure per'vaded the whole place, and $I$ have no doubt helped to cause his illness. A flydriver's wife, living in rooms over a coach-house, was suffering from low fever, which I attributed to the smell of stable-manure. In several other instances it has appeared to me that serious illness was cansed by living over stables. A gentleman in London was made ill by the smell from the stable which penetrated into the dwellinghouse.

One mole case I must give. A gentleman was confined to his hed with a fractured patella. About the sixteenth day he was attacked with pneumonia, for which no other cause could be traced 
than the emanations from a neighbouring water-closet. The door of this was generally left ajar, and the place had, as usual, but a single window for ventilation. A somewhat similar case occurred with a woman in child-bed, mild fever being the result.

These are but samples of much more that could be given. It is not safe to believe that the first rudiments of sanitary science have been sufficiently taught. There are many people who either do not know them, or, what is even more frequent, do not attend to them and caryy out their teachings. Cesspools are not yet things of the past. Refuse-heaps, manurc-heaps, offensive trades, crowded collections of animals, yes, even sometimes of human animals, are not yet swept away. They are sometimes hid round colnel's, and in nooks, towards which the eyes of inspectors do not always seem to bend. I have seen nuisances, years ago complained of and supposed to be removed, still existing, and nearly in the original state; sanitary ovils, long pointed out, not yet remedied; nuisances, which the arm of the liw ought to have long ago reached, but which it seems to have no power to interfere with. In short, considering the talk and stir. about sanitary matters which has gone on for these thirty years, and allowing for good things done and arrnugements made, it looks as if some localities were not much the better for it all. It mav be that lealth officer's do not find themselves sufficiently free to do their whole duty. It is certain that some of them are very insufficiently paid. And it is also certain, that sanitary measures are not yet supported by the roice and vote of the whole community, and that both the knowledge and the disposition to do these things rightly are not yet possessed by all.

W. E. C. Nourse, F.R.C.S.

\section{On the Past and Present Prevalence of several Dis- eases, as influenced by Food, and by House Drainage.}

THE following remarles relate to the causation and prevention of diseases, the object of all sanitary work. This kind of work is, we lnow, of quite recent origin; some of us may have helped, in our day, to develop it; yet, long ago, before the work or its name was thouglit of, the progress of human improrement did something to banish clisense.

Thus, during the middle ages, leprosy was so common in the British Islands, that leper-hospitals were founded everywhere, and their sites are still known by the name 'Spital.' Leprosy receded and grew less common, according as improvements in agriculture and horticulture, and in the rearing of live stock, furnished better, more regular, and more abundant supplies of food, both animal and vege- 